\title{
COMPLEX APPROACH TO TREATMENT OF SUBCHORIONIC HEMATOMA IN EARLY THREATENED ABORTION
}

\author{
S. N. Heryak, N. V. Petrenko, I. Ya. Kuziv, O. Y. Stelmakh, \\ N. I. Bagniy, I. V. Korda, V. Yu. Dobryanska, L. V. Bagniy \\ I. HORBACHEVSKY TERNOPIL STATE MEDICAL UNIVERSITY, TERNOPIL, UKRAINE
}

Background. Currently, miscarriage is considered to be a multietiological disorder with trombofilic violations and hormone deficiency as the leading factors. Despite the achievements in treatment of miscarriage, the frequency of preterm termination of the wanted pregnancies is still high and the number of perinatal losses is significant. Therefore, pathogenetically based therapy, safe for the foetus, is very important in management of pregnancy interruption in the first trimester. A proper drugs administration provides optimal concentration of active ingredients and fast action. The aim is to improve effectiveness of the early threatened abortion treatment in cases of subchorionic hematoma (SCH) by combination of sublingual natural micronized progesterone and tranexamic acid

Objective. We examined 50 pregnant women with early threatened abortion with SCH. We studied system of haemostasis, basic hormonal markers and ultrasound criteria of threatened abortion. We compared efficacy of treatment between traditional (supportive) therapy (sedation, spasmolytic, haemostatic drug) and combination of supportive therapy in combination with tranexamic acid and natural micronized progesterone.

Results. The result of lab tests showed minimal signs of hypercoagulation, hyperfibrinogenemia and platelet hyperactivity, a significant $\beta$-hCG level decrease and approximate decrease in progesterone and free estriol production.

Sonographic examination showed presents of local myometrial hypertonus, deformation of fertilized egg, hypoplasia of chorion, low location of fertilized ovum, retarded growth of CRL.

The research proved that combined administration of sublingual micronized progesterone and tranexamic acid for the treatment of threatened abortion with SCH has more significant positive effect for pregnancy maintenance due to clinical, biochemical, hormonal and ultrasound results if compared with the group which underwent supportive therapy.

Conclusions. Complex application of natural micronized progesterone $100 \mathrm{mg}$ three times a day sublingually and $500 \mathrm{mg}$ of Tranexamic acid dissolved in $200 \mathrm{ml}$ normal saline solution improves the dynamics of the main hormonal, haemostatic and ultrasound markers of abortion and significantly reduces reproductive losses. Tranexamic acid treatment proved a rapid and effective action on hematoma and absence of embryotoxical and coagulopathyc influence. Tranexamic acid does not cause any significant disorders of hemostatic system. This is very important at the early gestation because of intravascular coagulation, physiological hypercoagulable condition during pregnancy that can cause microthrombosis and disrupt placentation. On the other hand, it is dangerous for the mother's health because of the increased risk of thrombosis.

KEY WORDS: threatened miscarriage, subhorial hematoma, micronized progesterone, tranexamic acid.

\section{Introduction}

Currently, miscarriage is considered to be a multietiological disorder with trombofilic violations and hormone deficiency as the leading factors. The problem of early pregnancy loss remains urgent because these factors are the most common complications without any

Corresponding author: Svitlana Heryak, Department of Obstetrics and Gynecology No 2, I. Horbachevsky Ternopil State Medical University, 1 Maidan Voli, Ternopil, Ukraine, 46001 Tel.: +380352254891

E-mail:heryak@tdmu.edu.ua downward tendency [1-4]. According to the latest concepts, $80 \%$ of all pregnancy losses occur at the early stages. One of the first signs that threatens the pregnancy is subchorionic hematoma $(\mathrm{SCH})[5,6]$. It is the most unfortunate sign of threatened abortion. It is established that the disruption of trophoblast invasion in the $1^{\text {st }}$ trimester of pregnancy leads to the advanced gestational complications: threatened abortion, preeclampsia, preterm delivery, placental abruption, which increase perinatal, infant and 
maternal mortality. The protective function of the immune system at the early stages of gestation such as the suppression of natural killer cells in the endometrium, mother's blocking factors production is provided by different mostly hormonal dependent mechanisms; their disorders lead to defects of implantation, $\mathrm{SCH}$ and can cause early pregnancy termination $[3,7]$.

The endometrium and decidua contain a huge number of immune system cells, all of them are able to secrete cytokines. Main cytokines that are secreted in the body inhibit the embryo development, proliferation and development of normal trophoblast. They affect the embryo, both directly and indirectly, depending on the intensity of secretion and differentiation of target tissues [6]. Cytokine cascade can be triggered by infectious agent and by endogenous factors (hypoxia, hormones, etc.) as well. Persistent viral bacterial infection, neuroendocrine disorders, chromosomal abnormalities, the toxic effects, stress and environment are also etiological factors of early abortion $[8,9]$. Despite the achievements in treatment of miscarriage, the frequency of preterm termination of the wanted pregnancies is still high and the number of perinatal losses is significant. Therefore, pathogenetically based therapy, safe for the foetus, is very important in management of pregnancy interruption in the first trimester. A proper drugs administration provides optimal concentration of active ingredients and fast action.

The aim is to improve effectiveness of the early threatened abortion treatment in cases of subchorionic hematoma by combination of sublingual natural micronized progesterone and tranexamic acid.

\section{Materials and Methods}

The examination of 50 pregnant women was conducted at the Department of Gynaecology of Ternopil Regional Perinatal Centre "Mother and Child". They received treatment for threatened abortion in gestational age from 8 to 12 weeks. All women were diagnosed with $\mathrm{SCH}$ by means of ultrasound.

To exclude infection as an etiological factor of abortion, bacteriological research of TORCH and sexually transmitted infections were conducted. All patients had negative results of the tests for these infections.

System of haemostasis was evaluated by determination of platelet and aggregation time, prothrombin index (PI), thrombin clotting time, activated partial thromboplastin time (APTT), fibrinogen concentration.
Basic hormonal markers of abortion were also studied: the concentration of free estriol and progesterone by radioimmunoassay method, sets made by company "SORIN" (France), and radioisotope sets Amerlayt made by international company Amersham. $\beta$-subunit of human chorionic gonadotropin ( $\beta$-hCG) concentration was determined by immune fluorescence analysis with time resolution (test system Delfiya, Wallac, Perkinelmer) (according to the manufacture standard protocol of test systems).

To determine efficacy of the proposed complex of therapeutic measures, all the pregnant were tested with transvaginal ultrasound on the $14^{\text {th }}$ day of the treatment.

The pregnant of the $1^{\text {st }}$ group ( $n=25$; the comparison group) received supportive therapy - sedation, spasmolytic, haemostatic drug. The pregnant of $2^{\text {nd }}$ group $(n=25)$, together with supportive therapy, received tranexamic acid 2 $\mathrm{ml}(500 \mathrm{mg}$ ) dissolved in $200 \mathrm{ml}$ normal saline solution intravenously till the arrest of bleeding and natural micronized progesterone $100 \mathrm{mg}$ three times a day sublingually. The control group consisted of 20 healthy pregnant women without any symptoms of threatened abortion.

\section{Results and Discussion}

The evaluation of plasma-coagulation and vascular-platelet hemostasis showed minimal signs of hypercoagulation, hyperfibrinogenemia and platelet hyperactivity if compared with the women with physiological pregnancy. This suggests a thrombophilia as an etiopathogenetic factor of early abortion with $\mathrm{SCH}$ in the examined women.

The evaluation of hormonal homeostasis showed, that at the early gestational age a significant $\beta$-hCG level decrease and approximate decrease in progesterone and free estriol production were the diagnostic markers of threatened abortion with $\mathrm{SCH}$

The results of ultrasound examination showed, that $\mathrm{SCH}$ was located in the area of the lower chorion in $32(64 \%)$ of the pregnant women, in the central part - in $18(36 \%)$ patients. Also sonographic examination showed other markers of abortion. So, local myometrial hypertonus was diagnosed in $43(86 \%)$ pregnant women, deformation of fertilized egg - in 32 (64\%), hypoplasia of chorion - in $12(24 \%)$, low location of fertilized ovum $-8(16 \%)$, retarded growth of CRL - in 2 (4\%).

The research proved that combined administration of sublingual micronized progesterone 
and tranexamic acid for the treatment of threatened abortion with SCH has more significant positive effect for pregnancy maintenance due to clinical, biochemical, hormonal and ultrasound results if compared with the group which underwent supportive therapy.

After the symptomatic treatment a spontaneous abortion happened in 6 (24\%) women, missed abortion in - 6 (24\%), gestational process complicated by hyperemesis gravidarum which required additional therapy - in 4 (16\%). Among 25 women of the $2^{\text {nd }}$ group spontaneous abortion occurred in 3 (12\%) patients, missed abortion - in 1 (4\%) woman.

The results of our research have shown that in women of the $2^{\text {nd }}$ group the level of platelets increased and did not significantly differ from the control group findings. In patients of the $1^{\text {st }}$ group it was significantly lower than in women of the $2^{\text {nd }}$ and control groups. The similar changes were evidenced in the evaluation of PI.

In 2 weeks of the proposed therapy, the level of $\beta$-hCG increased in both groups of women, but in the 2nd group it did not significantly differ from the control group. After the treatment the level of free estriol and progesterone increased and did not significantly differ from the control group with the similar results.

Symptomatic and complex treatment significantly reduced the sonographic signs of abortion, but in the $2^{\text {nd }}$ group these changes pronounced more positive trend than in the $1^{\text {st }}$ group. So, in 18 (72\%) pregnant women of the $2^{\text {nd }}$ group and in $4(16 \%)$ - of the I group $(p<0,05)$ there was a complete resumption of $\mathrm{SCH}$,

\section{References}

1. Венцківський БМ. Стан імунного та гормонального статусусфетоплацентаного комплексу при недоношуванні вагітності. Педіатрія, акушерство та гінекологія 2012; 3: 40-43.

2. Резніченко ГІ. Профілактика невиношування вагітності і передчасних пологів. Жіночий лікар 2013; 3: 10-12.

3. Soldo V, Cutura N, Zamurovic M. Threatened miscarriage in the first trimester and retrochorial hematomas: sonographic evaluation and significance. Clin Exp Obstet Gynecol 2013; 40(4): 548-50.

4. Şukur YE, Goç G, Kose O, Acmaz G, Ozmen B, Atabekoglu CS, Koc A, Soylemez F. The effects of hematoma decreased in size in $3(12 \%)$ women of each group.

Thus, the prescription of micronized progesterone sublingually provides an inhibitory effect on the contractile activity of myofibrils, prevents the further chorine detachment that leads to pregnancy maintenance and prevents reproductive losses.

Our research demonstrates the necessity of the inclusion of micronized progesterone in $100 \mathrm{mg} 3$ times daily sublingually and tranexamic acid $500 \mathrm{mg}$ intravenously to the treatment protocol of early threatened abortion with $\mathrm{SCH}$. Also this treatment is more effective if compared with the traditional supportive therapy (sedation, spasmolytic, haemostatic drug).

\section{Conclusions}

1. Complex application of natural micronized progesterone $100 \mathrm{mg}$ three times a day sublingually and $500 \mathrm{mg}$ of Tranexamic acid dissolved in $200 \mathrm{ml}$ normal saline solution improves the dynamics of the main hormonal, haemostatic and ultrasound markers of abortion and significantly reduces reproductive losses.

2. Tranexamic acid treatment proved a rapid and effective action on hematoma and absence of embryotoxical and coagulopathyc influence. Tranexamic acid does not cause any significant disorders of hemostatic system. This is very important at the early gestation because of intravascular coagulation, physiological hypercoagulable condition during pregnancy that can cause microthrombosis and disrupt placentation. On the other hand, it is dangerous for the mother's health because of the increased risk of thrombosis.

subchorionic hematoma on pregnancy outcome in patients with threatened abortion. J Turk Ger Gynecol Assoc 2014; 15(4): 239-242.

5. Dongol A, Mool S, Tiwari P. Outcome of pregnancy complicated by threatened abortion. Kathmandu Univ Med J 2011; 9(33): 41-44.

6. Odeh M, Ophir E, Grinin V, Tendler R, Kais M, Bornstein J. Prediction of abortion using threedimensional ultrasound volumetry of the gestational sac and the amniotic sac in threatened abortion. J Clin Ultrasound 2012; 40(7): 389-393.

7. Biesiada L, Krekora M, Krasomski G. Subchorionic hematomaas a risk factor of pregnancy and 
delivery in women with threatening abortion. Ginekol Pol 2010; 81(12): 902-906.

8. Hodgson DT, Lotfipour S, FoxJC. Vaginal bleeding before 20 weeks gestation due to placental abruption leading to disseminated intravascular coagulation and fetal loss after appearing to satisfy criteria for routine threatened abortion: a case report and brief review of the literature. J Emerg Med 2009; 32(4): 387-392.

9. Stamatopoulos N, Lu C, Infante F, Menakaya U, Casikar I, Reid S, Mongelli M, Condous G. Does the presence of subchorionic haematoma increase the risk of miscarriage? Ultrasound in Obstetrics \& Gynecology 2013; 42 (1): 54. 